\title{
Operating Experience and Teardown Analysis for Engines Operated on Biodiesel Blends (B20)
}

\author{
Richard Fraer and Han Dinh \\ United States Postal Service

\begin{abstract}
Kenneth Proc and Robert L. McCormick
National Renewable Energy Laboratory-U.S. Department of Energy
\end{abstract} \\ Kevin Chandler \\ Battelle \\ Bruce Buchholz \\ Lawrence Livermore National Laboratory—U.S. Department of Energy
}

Copyright @ 2005 SAE International

\begin{abstract}
Biodiesel has been used to reduce petroleum consumption and pollutant emissions. B20, a 20\% blend of biodiesel with $80 \%$ petroleum diesel, has become the most common blend used in the United States. Little quantitative information is available on the impact of biodiesel on engine operating costs and durability. In this study, eight engines and fuel systems were removed from trucks that had operated on B20 or diesel, including four 1993 Ford cargo vans and four 1996 Mack tractors (two of each running on B20 and two on diesel). The engines and fuel system components were disassembled, inspected, and evaluated to compare wear characteristics after 4 years of operation and more than 600,000 miles accumulated on B20. The vehicle case history-including mileage accumulation, fuel use, and maintenance costs-was also documented. The results indicate that there was little difference that could be attributed to fuel in operational and maintenance costs between the B20- and diesel-fueled groups. No differences in wear or other issues were noted during the engine teardown. The Mack tractors operated on B20 exhibited higher frequency of fuel filter and injector nozzle replacement. Biological contaminants may have caused the filter plugging. A sludge buildup was noted around the rocker assemblies in the Mack B20 engines. The sludge contained high levels of sodium, possibly caused by accumulation of soaps in the engine oil from out-of-specification biodiesel. The Mack and Ford engines used similar pump-line nozzle fuel injection systems, but a much larger volume of fuel was recirculated in the larger Mack engines. This, along with duty cycle and engine loading, may account for the difference in performance of the two engine types operated on B20.
\end{abstract}

\section{INTRODUCTION}

Biodiesel is an oxygenated fuel or blending component made from vegetable oils, waste cooking oil, or animal fats by reaction of the triglyceride fats with methanol to form methyl esters via transesterification. Biodiesel or biodiesel blends are used by fleets and other vehicle users to reduce petroleum consumption and pollutant emissions, and to comply with mandates for the use of alternative fuels. Significant reductions of particulate matter, carbon monoxide, and hydrocarbon emissions can be achieved with biodiesel use [1]. Lifecycle analysis indicates that biodiesel is highly renewable, thus its use results in real reductions in petroleum consumption and carbon dioxide emissions [2]. Minor impacts in peak torque and fuel economy are related to the lower energy density of biodiesel fuels, but thermal efficiency is unchanged [3].

The Energy Policy Act of 1992 (EPAct), as amended in 1996, added biodiesel to the list of approved alternative fuels (which also includes compressed natural gas, electricity, etc.). EPAct requires a percentage of new light-duty vehicle acquisitions by certain fleets to be alternative fuel vehicles (AFVs): $75 \%$ for federal and state fleets and $90 \%$ for alternative fuel provider fleets. Vehicles certified to run on B100 could qualify under the AFV purchase provisions of EPAct, but vehicles meeting this requirement are not available today. With the Energy Conservation Reauthorization Act of 1998, EPAct was amended to allow qualified fleets to use B20 ( $20 \%$ blend of biodiesel with $80 \%$ petroleum diesel) in existing vehicles, either heavy-duty or light-duty, to generate AFV purchase credits, with some limitations. This has created significant B20 use by government and alternative fuel provider fleets. 
However, B20 operational data are not readily available from the engine and fuel system manufacturers or fleet users. In fact, engine and vehicle manufacturers have expressed concern about the limited information available on the effects of biodiesel and biodiesel blends on extended engine durability and operating costs. Fleets and other potential users also lack technical inuse data to support decisions about the use of biodiesel blends in their vehicles. This lack of information is a major barrier to B20 market penetration and acceptance.

\section{OBJECTIVE}

The work described in this paper provides quantitative in-use data on the operating cost and engine durability impacts of B20 use in U.S. Postal Service (USPS) vehicles. This was accomplished through teardown analysis of engines and fuel systems removed from these vehicles and comparisons of wear characteristics to standard diesel vehicles operated in the same service. Engine- and fuel-related maintenance costs were also compared.

\section{PREVIOUS STUDIES}

Since the mid-1990s, several studies have reported on extended vehicle operation. Malcosky and Wald [4] reported on roughly 10 months of operational experience of five dump truck/snow plows on B20, with a control group operating on conventional diesel. A total of 60,000 miles of B20 operation had been accumulated at the time of the report. A focus of the study was on maintaining fuel quality by using new or clean fuel storage tanks. Another focus was on procedures for blending biodiesel to produce homogenous $20 \%$ blends. No significant differences in performance or maintenance costs were identified for the B20 vehicles versus the diesel control vehicles.

Bickel and Strebig [5] reported on a 2-year field trial of B20 use in road maintenance vehicles in Minnesota. Nearly 25,000 gallons of B20 were consumed over roughly 135,000 miles of operation during the trial, and the B20 vehicles exhibited the same average fuel economy (in miles per gallon) as the diesel control vehicles. Oil analysis was conducted at 5,000-mile intervals and indicated that no unusual engine wear or fuel dilution were occurring. Inspection of engine fuel systems at the conclusion of the trial showed no signs of unusual wear or deposits.

Kearney and Benton [6] reported on a 1-year B20 demonstration at Scott Air Force Base in Illinois. Fuel quality was monitored during the demonstration. Military specifications limited solids content to $9.46 \mathrm{mg} /$ quart via a procedure similar to ASTM D6217. Several loads of B20 exceeded this limit by a significant amount, many containing visible solids. Nevertheless, no filter plugging or other operational problems were reported.

Humberg et al. [7] recently surveyed the experience of state transportation agencies with B20. Roughly half of the states using B20 reported more fuel filter plugging issues with B20 than with petroleum diesel. Many states also reported small declines in fuel economy with B20. No noticeable changes in fuel pump and fuel injector durability or unusual impacts on engine oil analyses were reported.

Chase et al. [8] described operation of a heavy-duty linehaul truck on a blend of $50 \%$ biodiesel and $50 \%$ No. 2 diesel (B50) for more than 200,000 miles. Extensive inspection and analysis of the engine at the conclusion of the study showed no excessive wear, and tests indicated no injector degradation.

Although most of these prior studies report fuel use, mileage, and fuel economy, only one included detailed analysis of engine wear following biodiesel blend use, and none discuss maintenance costs quantitatively. This study looks in more detail at the impacts of B20 on engine wear and engine operability.

\section{UNITED STATES POSTAL SERVICE BIODIESEL BLEND USE}

The USPS operates the largest and most visible civilian vehicle fleet in the world: more than 212,000 vehicles ranging from heavy-duty trucks to minivans and passenger cars [9]. The USPS also maintains the largest AFV fleet in the United States, which includes vehicles fueled with ethanol, natural gas, propane, electricity, and biodiesel.

B20 has been used to demonstrate the USPS's commitment to energy independence and the environment, and to meet EPAct federal fleet requirements. One biodiesel fuel use credit, which is counted as one AFV acquisition, is allocated for each purchase of 450 gallons of neat $(100 \%)$ biodiesel or 2,250 gallons of B20. Because of the increased use of biodiesel, the USPS has met or surpassed its EPAct requirements for the past 8 years, often by $10 \%$ or more.

The USPS is one of the first federal agencies to use B20. B20 use was initiated about 5 years ago in Manhattan, New York; Detroit, Michigan; St. Louis, Missouri; and Miami, Florida. In some locations, the fuel supply comes from a mobile refueler. The mobile refueler eliminates the need to own and maintain fuel tanks. Biodiesel and biodiesel blends have been known to promote microbial growth in fuel storage tanks under certain conditions. In 2004, 929 USPS cargo vans, truck tractors, spotter tractors, and step vans were using B20. B20 consumption during 2000-2004 is shown in Figure 1 [10]. B20 consumption declined in 2004 because of a fuel filter-plugging problem at the Miami location. 


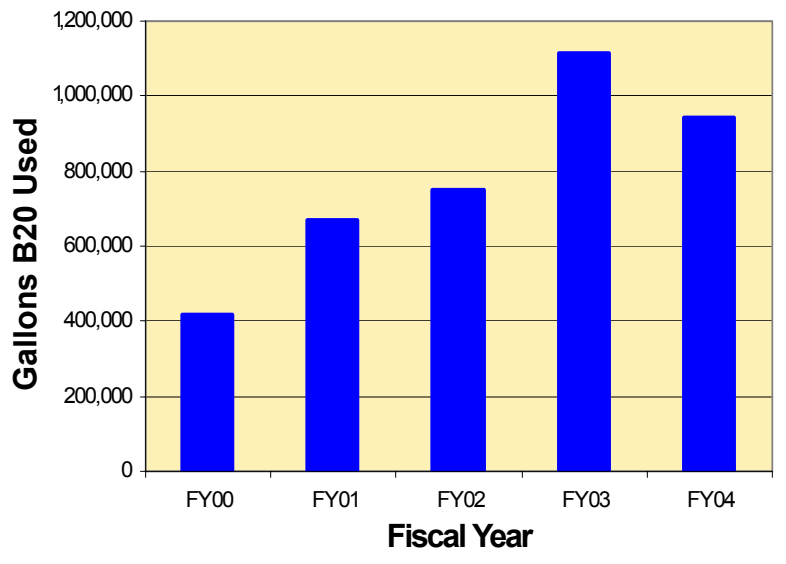

Figure 1. Fiscal Year 2000-2004 USPS B20 Consumption

B20 generally has cost more than conventional diesel, which limits the use of B20 in many locations. As of August 11, 2005, B20 averaged $\$ 2.11$ in the United States compared to $\$ 1.94$ for \#2 diesel (taxes not included) [11]. A new biodiesel tax incentive signed by President Bush became effective on January 1, 2005, and has great potential to reduce the price difference, thus promoting the expansion of biodiesel blend use without placing a financial burden on local fleet managers [12].

\section{APPROACH}

With the planned replacement of the cargo vans in 2004 and truck tractors in 2005, the USPS had a unique opportunity to examine these vehicles before they were removed from the fleet and sold to the public. Typically, these vehicles are replaced when age and maintenance costs exceed established replacement criteria such as 8 years and 360,000 miles.

The engines and fuel system components were disassembled, inspected, and evaluated to compare wear characteristics after several years of operation. Vehicle case histories-including mileage accumulation, fuel use, and maintenance costs-were also documented.

\section{VEHICLE SELECTION}

Selection of USPS trucks focused on the Miami Vehicle Maintenance Facility (VMF) because of its B20 use for all diesel equipment from approximately October 1999November 2003. The next criterion was to consider heavy trucks that were either close to the end of their useful life or near an engine rebuild threshold, so the study trucks could have their engines removed and disassembled for detailed study. The USPS identified two potential fleet candidates: model year (MY) 1993 Ford 9-ton cargo vans and MY 1996 Mack tractors (Figures 2 and 3). The Mack tractor is used in daily operations to transport trailers of mail and equipment to and from Processing and Distribution Centers (P\&DCs).
The Ford cargo van is used to transport large volumes of mail from mailers' plants and P\&DCs to post offices and airmail facilities. The candidate Ford vans were near the end of their useful life. The Mack tractors were nearing a scheduled engine rebuild.

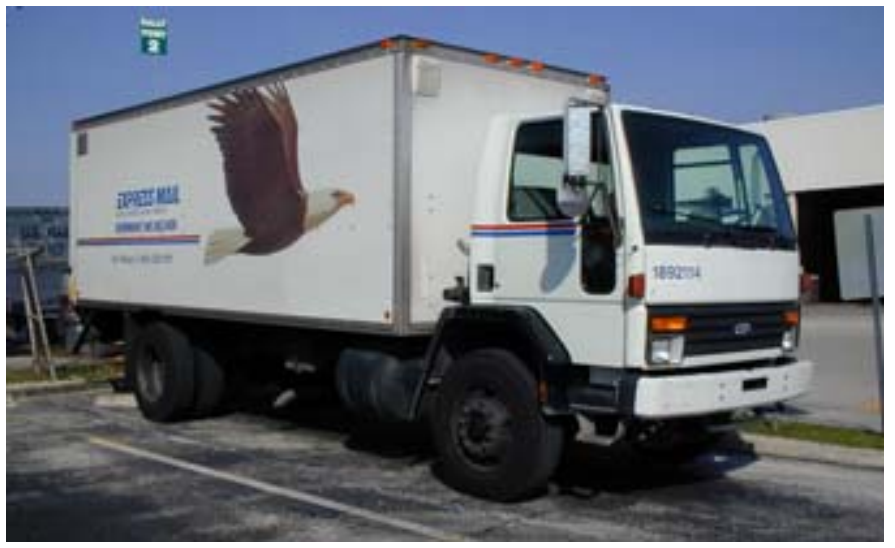

Figure 2. 1993 Ford 9-Ton Cargo Van

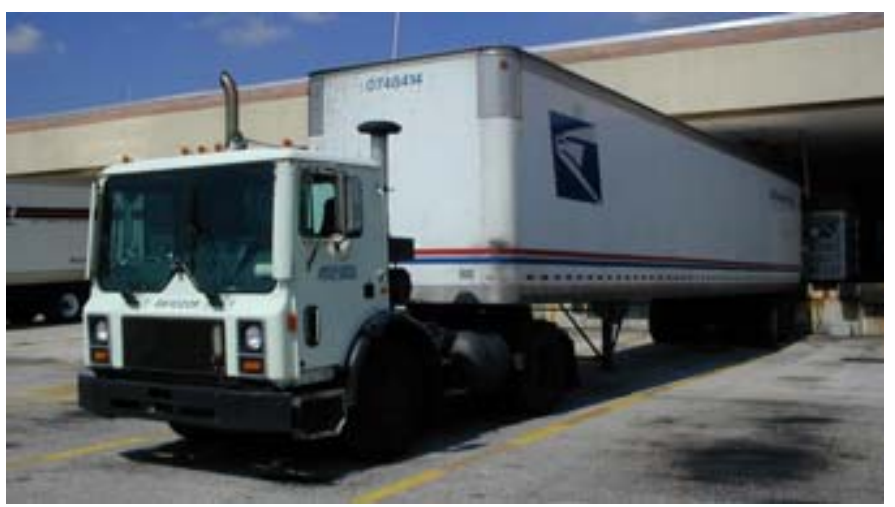

Figure 3. 1996 Mack Tractor

Four of the Ford vans and four of the Mack tractors were selected for the study. Two of each type of vehicle were selected from the Miami VMF as the B20 study vehicles. Two control vehicles of each type were also selected. So that these diesel-only control vehicles operated on a similar duty cycle and in a similar climate as the B20 vehicles, two Mack tractors were selected from the Ft. Lauderdale VMF and two Ford vans from the Tampa VMF.

\section{TEARDOWN PROCEDURE}

Roush Industries performed engine removal, disassembly, inspection, evaluation, and rebuild (Figure 4). The Bosch fuel injection pumps were tested, disassembled, inspected, and rebuilt by a fuel systems facility (Superior Turbo \& Injection, Detroit, Michigan), which was approved and recommended by Robert Bosch North America. Internal parts were compared for wear, breakage, or other damage as well as the accumulation of dirt, sludge, and carbon deposits in an effort to uncover effects attributable to the type of fuel used. The essential results of the evaluation are 
summarized in four general areas, which represent the overall condition of the engines:

- Cylinder heads and combustion chambers

- Cylinder block and crankcase

- Lubrication system

- Fuel system

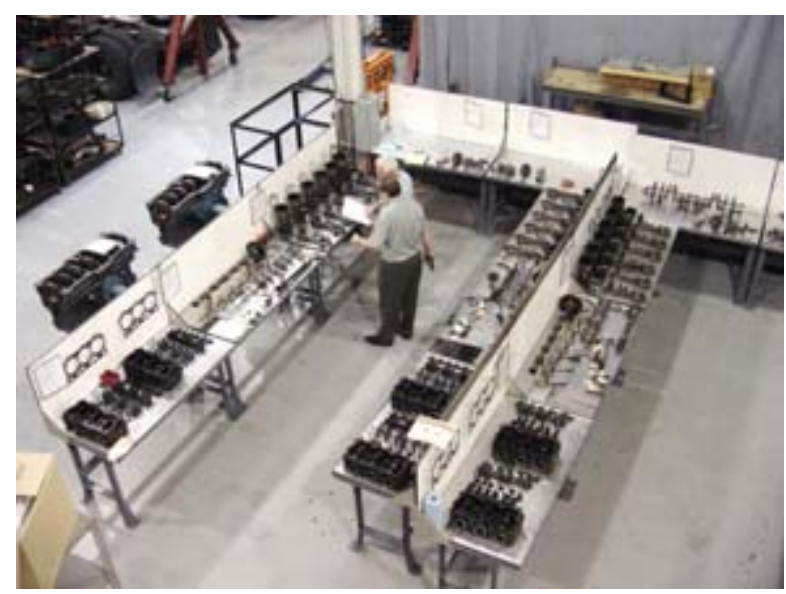

Figure 4. Teardown Inspection at Roush

\section{VEHICLE MAINTENANCE COMPARISON}

The general approach for the vehicle maintenance cost comparison analysis was to collect all work orders available for each of the eight study vehicles. The focus was the maintenance costs for each vehicle that were related to the fuel system or engine. Labor costs were held to a constant $\$ 50$ per hour, and parts costs were not corrected for inflation; however, the data presented here were from a similar period for each vehicle.

The engine and fuel maintenance cost data were used to compare the diesel-only and B20 trucks to determine differences that might have been caused by the use of B20. The maintenance data were also used to investigate issues identified in the engine teardown analysis.

\section{VEHICLE INFORMATION}

The USPS purchased the new Mack tractors and Ford vans in large block purchases of approximately 900 Mack tractors and 2,400 Ford vans. Table 1 provides specific information about the eight study vehicles. "Vehicle Mileage at Teardown" indicates the mileage at which the engines were removed from the vehicles for detailed study. "Engine Number in Teardown" is a crossreference for identifying vehicles in the detailed engine teardown discussions. Table 2 provides general specifications for the study vehicles and engines.

\section{PERIODS OF OPERATION}

The Ford van fleet was placed into service in early 1993. The South Florida District, which includes the Miami and $\mathrm{Ft}$. Lauderdale VMFs, had 13 of the Ford vans in operation up to the start of this study. The South Florida District also has 43 Mack tractors, which started operation in late 1996. The Miami VMF started using B20 in October 1999 and used it almost exclusively until November 2003, consuming more than 1 million gallons of $\mathrm{B} 20$ over this period.

USPS VMFs generally keep at least 2 years of paper maintenance records on hand. However, at the Ft. Lauderdale VMF work orders for the entire life of the study vehicles were available and collected for this study. At the Tampa VMF, only 2 years of work orders were available. At the Miami VMF, 2 years of work order records for the Ford vans were available and more than 4 years of the Mack work orders were collected. B20 use began before the collection of maintenance data for this study. The data collection periods are detailed in Table 3.

Table 1. USPS Study Vehicle Information

\begin{tabular}{|l|l|l|l|l|}
\hline $\begin{array}{c}\text { USPS Truck } \\
\text { Number }\end{array}$ & \multicolumn{1}{|c|}{ VIN } & $\begin{array}{c}\text { Vehicle } \\
\text { Mileage at } \\
\text { Teardown }\end{array}$ & $\begin{array}{c}\text { Engine } \\
\text { Make/Model }\end{array}$ & $\begin{array}{c}\text { Engine } \\
\text { Number in } \\
\text { Teardown }\end{array}$ \\
\hline 6610170 & 1M1K194YOVM009162 & 364,514 & Mack E7-300 & Mack \#1 \\
\hline 6610131 & 1M1K194Y1VM009123 & 395,584 & Mack E7-300 & Mack \#2 \\
\hline 6610209 & 1M1K194Y6VM009201 & 384,464 & Mack E7-300 & Mack \#3 \\
\hline 6610191 & 1M1K194Y8VM009183 & $339,916^{*}$ & Mack E7-300 & Mack \#4 \\
\hline 1891990 & 1FDXH81A4DVA17292 & 343,185 & Ford 7.8L & Ford \#1 \\
\hline 1892111 & 1FDXH81A8PVA21037 & 377,272 & Ford 7.8L & Ford \#2 \\
\hline 1892158 & 1FDXH81A6PVA23644 & 351,967 & Ford 7.8L & Ford \#3 \\
\hline 1892193 & 1FDXH81AXPVA25350 & 347,803 & Ford 7.8L & Ford \#4 \\
\hline
\end{tabular}

${ }^{*}$ Engine was rebuilt at 144,687 miles (mileage since overhaul is 195,229). 
Table 2. General Vehicle Specifications

\begin{tabular}{|c|c|c|}
\hline Vehicle Item & Mack Tractor & Ford Van \\
\hline $\begin{array}{l}\text { Vehicle } \\
\text { Manufacturer/Model }\end{array}$ & Mack MR688P & $\begin{array}{l}\text { Ford CF- } \\
8000\end{array}$ \\
\hline $\begin{array}{l}\text { Gross Vehicle Weight } \\
\text { Rating }\end{array}$ & $33,000 \mathrm{lb}$ & $33,000 \mathrm{lb}$ \\
\hline Curb Weight & $13,180 \mathrm{lb}$ & $14,980 \mathrm{lb}$ \\
\hline Engine & Mack E7-300 & Ford 7.8L \\
\hline Power Rating & $\begin{array}{l}300 \quad \mathrm{hp} @ \\
1,950 \mathrm{rpm} \\
1,160 \mathrm{ft}-\mathrm{lb} @ \\
1,200 \mathrm{rpm}\end{array}$ & $\begin{array}{l}210 \mathrm{hp} @ \\
2,300 \mathrm{rpm} \\
600 \mathrm{ft}-\mathrm{lb} @ \\
1,500 \mathrm{rpm}\end{array}$ \\
\hline Displacement & $12 \mathrm{~L}$ & $7.8 \mathrm{~L}$ \\
\hline Number of Cylinders & 6 & 6 \\
\hline Compression Ratio & $16.5: 1$ & $17.5: 1$ \\
\hline
\end{tabular}

Table 3. Data Periods, Mileage, and Fuel Economy

\begin{tabular}{|c|c|c|c|c|}
\hline $\begin{array}{l}\text { Study } \\
\text { Group }\end{array}$ & $\begin{array}{l}\text { Data } \\
\text { Period }\end{array}$ & $\begin{array}{l}\text { Total } \\
\text { Data } \\
\text { Period } \\
\text { Mileage }\end{array}$ & $\begin{array}{l}\text { Average } \\
\text { Monthly } \\
\text { Mileage } \\
\text { per } \\
\text { Vehicle }\end{array}$ & $\begin{array}{l}\text { General } \\
\text { Fuel } \\
\text { Economy } \\
\text { Range }\end{array}$ \\
\hline $\begin{array}{l}\text { Miami } \\
\text { Mack B20 }\end{array}$ & $\begin{array}{c}8 / 00- \\
9 / 04\end{array}$ & 349,874 & 3,499 & \multirow[b]{2}{*}{$\begin{array}{c}5.0-5.5 \\
\mathrm{mpg}\end{array}$} \\
\hline $\begin{array}{l}\text { Ft. } \\
\text { Lauderdale } \\
\text { Mack } \\
\text { Diesel }\end{array}$ & $\begin{array}{l}8 / 00- \\
9 / 04\end{array}$ & 422,260 & 4,223 & \\
\hline $\begin{array}{l}\text { Miami Ford } \\
\text { B20 }\end{array}$ & $\begin{array}{l}9 / 02- \\
9 / 04 \\
\end{array}$ & 146,201 & 2,924 & \multirow{2}{*}{$\begin{array}{c}7.0-9.0 \\
\mathrm{mpg}\end{array}$} \\
\hline $\begin{array}{l}\text { Tampa } \\
\text { Ford Diesel }\end{array}$ & $\begin{array}{c}9 / 02- \\
9 / 04\end{array}$ & 125,613 & 2,512 & \\
\hline
\end{tabular}

\section{FUEL USE AND MILEAGE ACCUMULATION}

Table 3 also summarizes mileage accumulation during the data collection period. The Miami Mack tractors had lower average monthly mileage than the Ft. Lauderdale Mack tractors; however, the average mileages are close enough to indicate that the vehicles were used generally in the same way. The tractors in the South Florida District are used for bulk movement of mail and packages to and from area distribution centers. The Ford vans had similar average monthly mileages, with the Miami vans slightly higher than the Tampa vans.

According to information provided by the VMFs, the Mack tractors had a fuel economy range around 5.0-5.5 $\mathrm{mpg}$, and the Ford vans had a fuel economy range around $7.0-9.0 \mathrm{mpg}$. These are estimated ranges because the USPS generally does not track fuel use by vehicle. The Miami VMF reported no discernible difference in fuel economy with B20 use.

\section{MACK TRACTOR RESULTS}

In examining the cylinder block, crankcase, and lubrication system of the Mack tractors, no significant differences were found between the B20 and diesel engines. The main bearings exhibited wear that was normal for the accumulated mileage. The No.1 and 2 B20 engines showed bearing wear into the copper linings (Figure 5), and the No. 3 and 4 diesel engines showed typical "hen-tracking" and "orange peel" (Figure 6). The crankpin bearings also exhibited normal wear, with wear into the copper lining on the upper inserts, except for the No. 4 diesel engine, which had lower accumulated mileage.

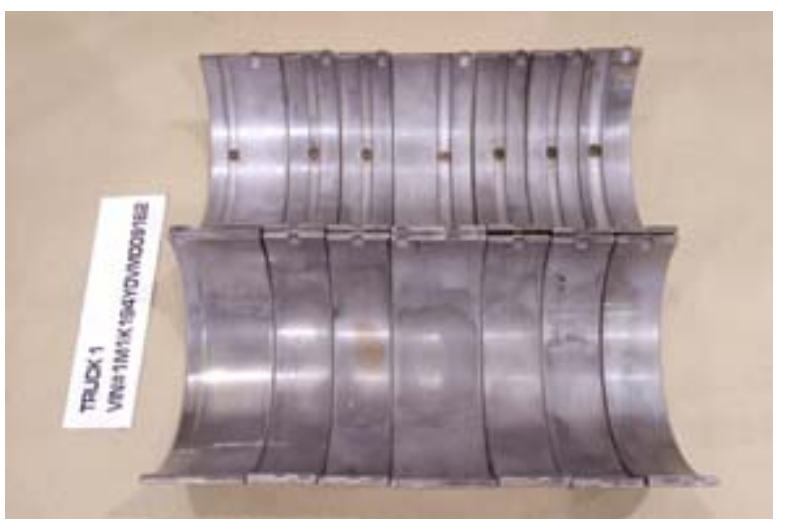

Figure 5. Mack No. 1 B20 Main Bearing Wear

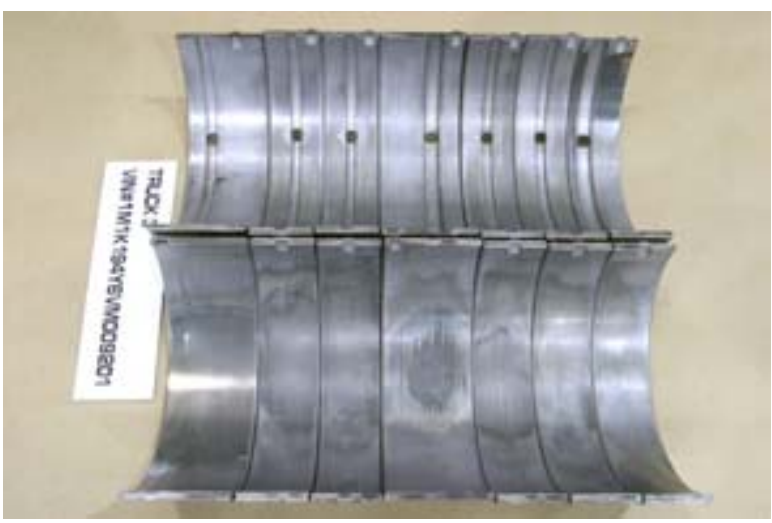

Figure 6. Mack No. 3 Diesel Main Bearing Wear

Minor differences were seen in the oil pump pressure relief valve pistons. The relief valve pistons in the No. 1 and 2 B20 engines showed scuffing and were not suitable for reuse (Figure 7). The No. 3 and 4 diesel relief valve pistons had only minor blemishes and could be reused (Figure 8 ). These minor differences may be attributable to differences in oil filters (B20 engines used reusable cartridges, diesel engines used a disposable spin-on type), but the observed wear was not unusual for the accumulated mileage. 


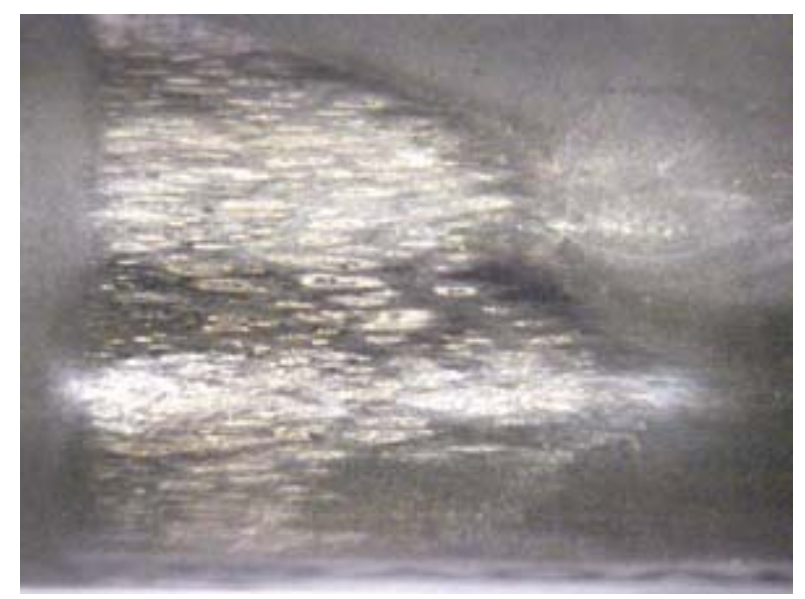

Figure 7. Mack No. 1 B20 Oil Pump Pressure Relief Valve Piston Wear

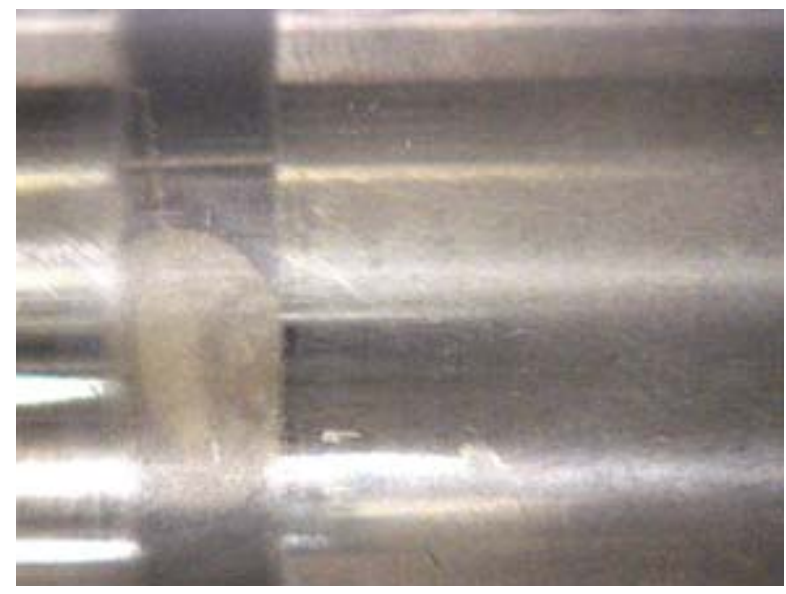

Figure 8. Mack No. 3 Diesel Oil Pump Pressure Relief Valve Piston Wear

\section{CYLINDER HEADS AND COMBUSTION CHAMBERS}

Upon inspection, no differences were seen in the pistons, intake, and exhaust valves. All components exhibited similar and expected amounts of carbon buildup on the combustion sides. However, the cylinder heads of the No. 1 and 2 B20 engines contained a heavy amount of sludge on the valve deck around the rocker assemblies (Figure 9).

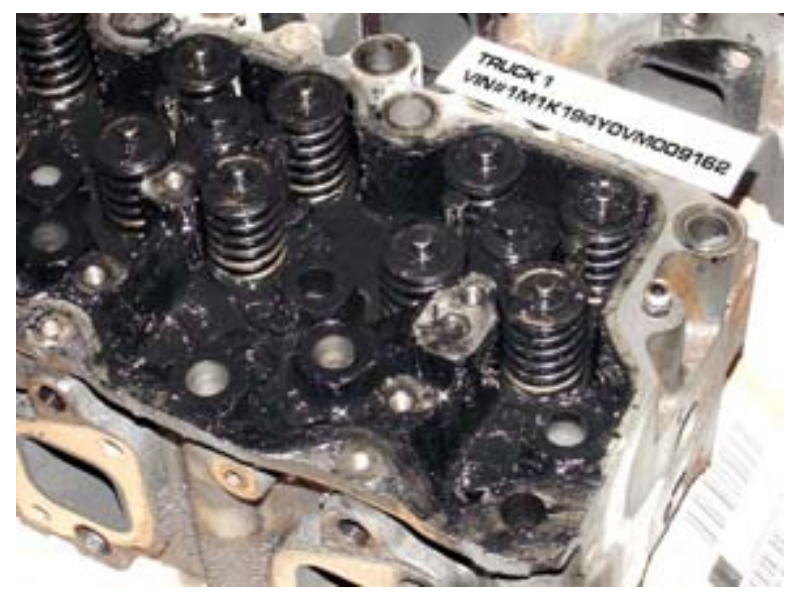

Figure 9. Mack No. 1 B20 Valve Deck Sludge Accumulation
The valve deck sludge was thick and gel-like compared with the oily residue found in the diesel engine heads. Figure 10 illustrates the difference between the substances found. The B20 sludge formed a pile on the sample card, whereas the diesel just left a stain. Looking closer at the differences between the sludge found in the No. 1 B20 engine head and the No. 2 B20 engine head, No. 2 had less accumulation and lighter consistency sludge with none found on the rocker assemblies. Maintenance records showed that the No. 2 B20 engine's injectors were replaced right after B20 use stopped (November 2003). The rocker assemblies likely were cleaned as part of the injector replacement and effort made to clean the cylinder head at that time.

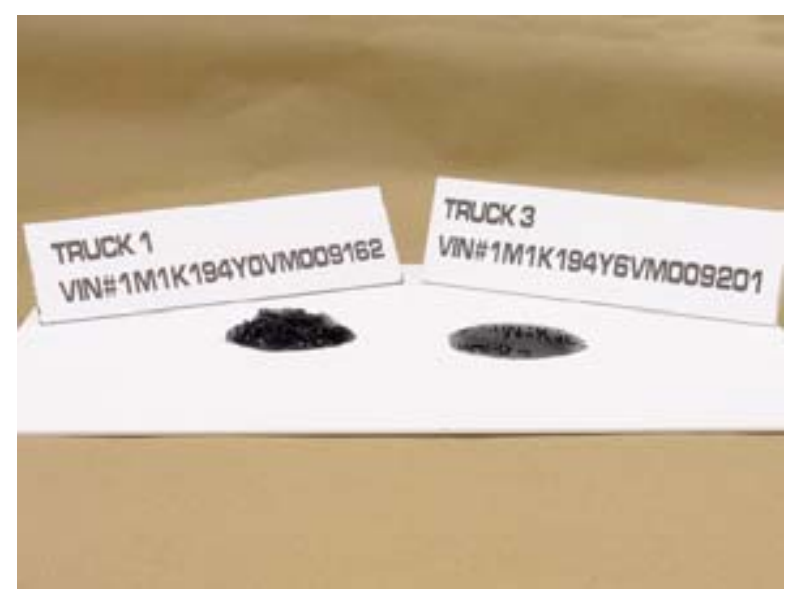

Figure 10. Cylinder Head Sludge Comparison (Mack No. 1 B20 vs. Mack No 3. Diesel)

\section{Sludge Analysis}

Analyses were performed to identify the source of the sludge. These included elemental analysis by inductively coupled plasma atomic emission spectroscopy (ICP, via ASTM D4951), infrared spectroscopy (FTIR-ATR), and isotopic analysis by accelerator mass spectrometry (AMS).

Results of the elemental analyses allow comparison of elements present in the sludge with those present in the engine lubricant (Table 4). This analysis was conducted on the two sludge samples from the B20 engines and the engine oil samples from all four engines. Considering that the B20 engines operated on B20 for 4 years, ending in 2003 , the engine oil samples would not be expected to exhibit effects from B20 but to be indicative of engine wear issues with other causes.

The engine oil typically contains calcium and/or magnesium from the detergent and zinc and phosphorus from the ZDDP anti-wear additive; all these metals were evident in the analysis. The sludge appeared to be enriched in calcium and zinc relative to the oils, with zinc and phosphorus present in roughly the correct proportions for ZDDP. Iron in the used oil samples was low, so wear problems were not evident. Iron was concentrated in the valve deck sludge, but these levels 
Table 4. Results of Metals Analysis (in ppm) by ASTM D4951 for Engine Oil and Valve Deck Sludge Samples

\begin{tabular}{|c|c|c|c|c|c|c|c|c|c|c|c|}
\hline & Silver & Boron & Calcium & Copper & Iron & Magnesium & Molybdenum & Sodium & Phosphorus & Silicon & Zinc \\
\hline $\begin{array}{c}\text { Engine \#1 } \\
\text { Oil }\end{array}$ & 2 & 70 & 3,880 & 1 & 13 & 18 & 0 & 0 & 1,081 & 0 & 1,231 \\
\hline $\begin{array}{c}\text { Engine \#1 } \\
\text { Sludge }\end{array}$ & 1 & 108 & 5,088 & 5 & 150 & 34 & 0 & 55 & 1,460 & 35 & 2,095 \\
\hline $\begin{array}{c}\text { Engine \#2 } \\
\text { Oil }\end{array}$ & 0 & 51 & 4,064 & 2 & 24 & 35 & 0 & 0 & 1,091 & 0 & 1,293 \\
\hline $\begin{array}{c}\text { Engine \#2 } \\
\text { Sludge }\end{array}$ & 0 & 158 & 9,156 & 6 & 110 & 58 & 0 & 165 & 1,759 & 33 & 2,408 \\
\hline $\begin{array}{c}\text { Engine \#3 } \\
\text { Oil }\end{array}$ & 6 & 20 & 2,933 & 4 & 21 & 302 & 25 & 0 & 1,273 & 0 & 1,506 \\
\hline $\begin{array}{c}\text { Engine \#4 } \\
\text { Oil }\end{array}$ & 1 & 10 & 2,916 & 22 & 43 & 314 & 26 & 0 & 1,270 & 0 & 1,530 \\
\hline
\end{tabular}

Levels of aluminum, barium, lead, chromium, nickel, antimony, tin, and vanadium were below detection limits.

were also low and probably not indicative of a wear problem.

Molybdenum is used in some engine oils as an antioxidant. Because the B20 and diesel engines were used in different fleets, the absence of molybdenum in the B20 engine oil samples suggests that this fleet employed an oil formulation that did not contain a molybdenum additive. The higher levels of magnesium in the oil from engines No. 3 and 4 support the idea that these engines operated on a different oil formulation.

The sludge is clearly enriched in sodium relative to the oils. Although there may be other sources of sodium contamination, a possible source for the B20 engines is biodiesel containing high levels of sodium as a residue from the biodiesel production process. Sodium hydroxide is used as a catalyst in biodiesel manufacturing, and, if not adequately removed, the sodium will form soaps that can cause a variety of operational problems.

Infrared spectroscopy provides a fingerprint of the various organic molecular structures present in the samples. FTIR spectra were acquired for the biodiesel fuel, unused engine oil, used engine oil from the two B20-fueled Mack engines, and the cylinder head sludge from these two engines. Results of the first efforts to analyze the sludge by FTIR were unsuccessful because of the overwhelming presence of carbonaceous material in the sludge. Particles were removed via absorbance on a special substrate after dilution with a high-volatility solvent that was later removed by evaporation. The liquid residue was then analyzed by FTIR. The B20 exhibited the distinctive carbonyl peak at about $1700 \mathrm{~cm}^{-}$ 1 , but this signal was not evident in either of the used engine oil or sludge samples. This argues against the participation of biodiesel in the sludge formation process. Finally, isotopic analysis was applied to determine the modern versus fossil carbon content of the sludge. The contemporary quantity of carbon-14 $\left({ }^{14} \mathrm{C}\right)$ in living things $\left(1.2\right.$ parts in $10^{12}=1$ modern) is highly elevated compared with the quantity of ${ }^{14} \mathrm{C}$ in petroleum-derived products $\left(<1\right.$ part in $10^{15}$ or instrument background). Accordingly, components of bio-derived fuels contain elevated ${ }^{14} \mathrm{C}$ compared with fossil fuels. This isotopic elevation is sufficient to trace the fate of bio-derived fuel components in the emissions or engine deposits of an engine using AMS [13-15]. AMS is an isotope ratio mass spectrometry technique in which ${ }^{14} \mathrm{C} /{ }^{13} \mathrm{C}$ ratios of the unknowns are normalized to measurements of four to six identically prepared standards of known isotope concentration. Typical samples are placed in quartz combustion tubes with excess copper oxide (CuO), evacuated, and combusted to $\mathrm{CO}_{2}$. The evolved $\mathrm{CO}_{2}$ is purified, trapped, and reduced to graphite in the presence of cobalt or iron catalyst in individual reactors [15]. All graphite targets were measured at the Center for AMS at Lawrence Livermore National Laboratory. A detailed description of the procedure for unfolding an isotope measurement to carbon source is available [16].

Results of the AMS analysis are shown in Table 5. The ${ }^{14} \mathrm{C}$ content of the $\mathrm{B} 20$ and motor oils were as anticipated (effectively zero or at instrument background for the motor oils). The sludge contained $1.3 \%-2.4 \%$ bio-derived carbon, an order of magnitude above the level observed in the motor oil. The presence of a measureable renewable component in the sludge supports the idea that the biodiesel fuel is involved in the processes leading to sludge formation.

Table 5. Results of Accelerator Mass Spectrometry Analysis of Modern Carbon Content

\begin{tabular}{cc}
\hline Sample & Fraction Modern Carbon \\
\hline Sludge 1 & 0.024 \\
Sludge 2 & 0.013 \\
Used oil 1 & 0.002 \\
Used oil 2 & 0.002 \\
New oil & 0.003 \\
B20 & 0.197 \\
\hline
\end{tabular}

Thus, the current hypothesis for the formation of the valve deck sludge is exposure of the engine to one or more off-specification batches of biodiesel blend containing high levels of sodium. Sodium soaps have a high boiling point and would concentrate in the engine oil. Because of the polyunsaturated nature of many of 
the fatty acid chains present in the biodiesel, soap (and possibly biodiesel) in the oil could undergo oxidative polymerization leading to deposits that clog oil drain passages. If this occurred in the valve deck area, engine oil would have a long residence time. This would lead to higher levels of decomposition and deposition of the detergent and anti-wear additives, consistent with the concentration of calcium, zinc, and phosphorus in the sludge. The FTIR carbonyl signature for biodiesel is not observed in the sludge either because the ester functionality decomposed in this relatively hightemperature environment or because the sample workup procedures applied to obtain an FTIR spectrum removed the biodiesel-containing components.

\section{FUEL SYSTEMS}

The fuel pumps did not show any difference between B20 and diesel engines. All four fuel injection pumps tested within the normal ranges for pressure and flow. Injection pump delivery valves exhibited little wear and were consistent for the four pumps. Fuel injectors, however, did have notable differences.

\section{$\underline{\text { Fuel Injector Nozzle Assemblies }}$}

All the fuel injector nozzle assemblies were removed, bench tested for leak-down rates, and then disassembled. The injector nozzles from No. 1 B20 were not within specified leak-down limits and required replacement (Figure 11). The No. 3 and 4 injector nozzles tested at the low end of the limits but could be reused. The No. 2 B20 injectors tested well within limits, confirming maintenance records of recent injector replacement. In comparing fuel injector nozzle replacements from the beginning of the data period (August 2000) until the time teardown was completed, both B20 engines required injector replacement, whereas the diesel engines did not.

\section{MACK MAINTENANCE COMPARISON}

Figure 12 shows engine- and fuel-related maintenance costs per vehicle mile for the two study groups of Mack tractors. These data points are a cumulative running average of the engine and fuel system costs per mile of operation. B20 use ended in November 2003. For most of the B20 data period the two groups of vehicles had essentially identical maintenance costs. However, in November 2003, the No. 2 B20 tractor had the complete set of six injectors and fuel pump replaced because of operational problems. This single event caused the cumulative average cost of maintaining the two B20 Mack tractors to increase by $\$ 0.01 / \mathrm{mile}$ or $28 \%$. This is reflected in Figure 12 as a step change occurring in November 2003.

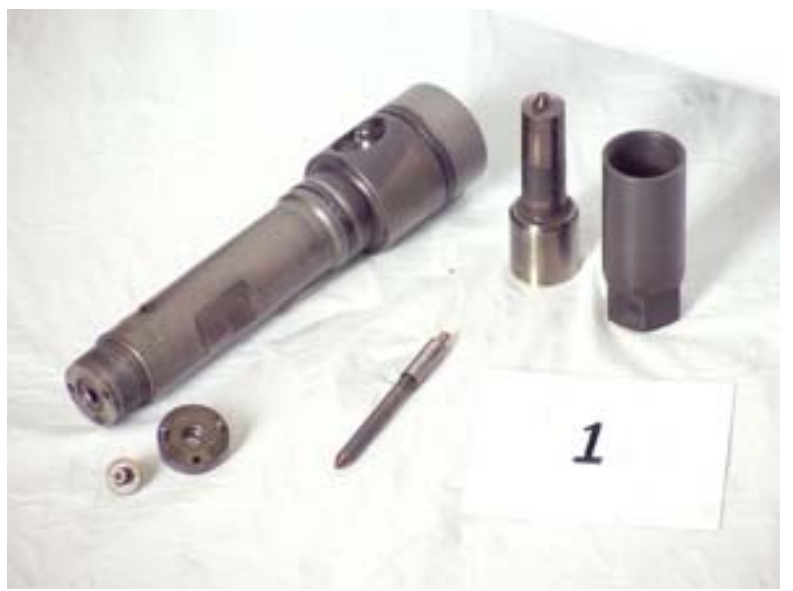

Figure 11. Mack No. 1 B20 Worn Fuel Injector Nozzle Disassembled

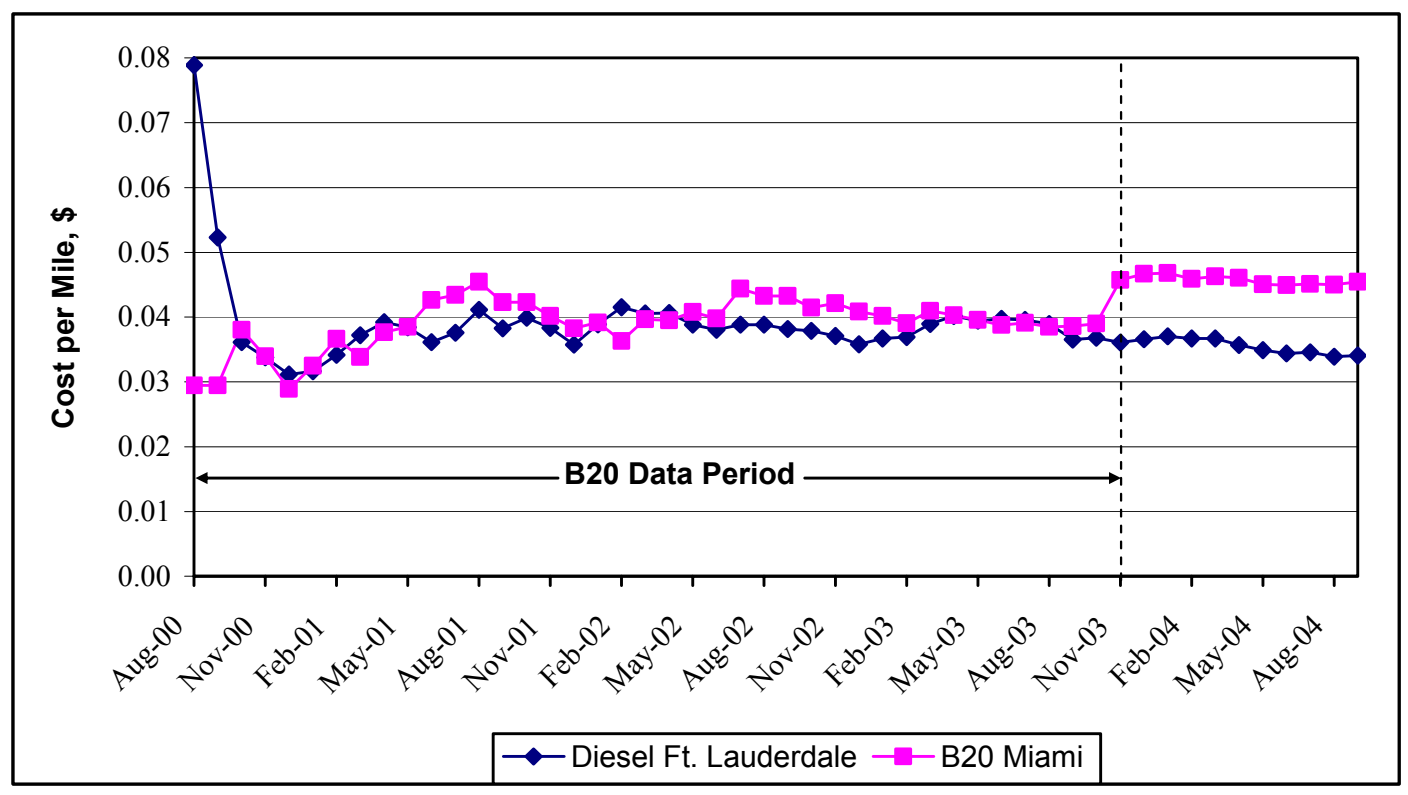

Figure 12. Cumulative Running Average Engine- and Fuel-Related Maintenance Costs per Mile for the Mack Tractors. Costs for the two groups of vehicles were the same for most of the study; however, an overall $\$ 0.01 /$ mile or $28 \%$ higher cost to maintain the B20 vehicles is attributed to a single event in Nov. 2003. 
Prior to the November 2003 event, Mack No. 2 B20 had significant unscheduled or roadcall repairs for the fuel system. In August 2001, the fuel tank on No. 2 B20 was cleaned out to remove "sludge." However, it should be noted that Mack No. 1 B20 did not have significant unscheduled or roadcall repairs for the fuel system or a "won't start" condition. While the injector and fuel pump replacement for vehicle No. 2 may be attributed to fuel quality issues, because no similar problems were exhibited by vehicle No. 1, the results are not conclusive.

As the analysis of maintenance results progressed, it became apparent that the two diesel-only Mack tractors at the Ft. Lauderdale VMF also had about 6-8 months of biodiesel blend operation in 2001. During this period, both of the diesel-only Mack tractors had multiple maintenance actions for "won't start," which resulted in fuel filter replacement. These unscheduled fuel filter replacements started at the end of 2000 and stopped around the end of July 2001. The Ft. Lauderdale VMF staff reported that they started using B20 at the end of 2000 but quickly stopped using it because of the fuel filter-plugging problem.

USPS personnel at the Miami VMF reported that during the B20 use period the Mack tractors had significant problems with the biodiesel blend. None of the other diesel equipment had significant problems with the biodiesel blend, only the Mack tractors. The problems with the biodiesel blend resulted in repeated fuel filter plugging. Based on the two Miami VMF Mack tractors studied here, the significant filter plugging problems did not necessarily affect every one of the Mack tractors. The Mack engine fuel system has a larger displacement pump and a greater diesel fuel recirculation volume than other engines in the fleet at that time. The USPS suspected that this difference was the reason for the fuel filter plugging, but its investigation into the source of the problem was not conclusive.

The USPS was not using any kind of additive in the diesel fuel or biodiesel blend because of a general policy of not using additives. This policy may need additional investigation with regard to the use of biodiesel blends. The suspected problem with the use of a biodiesel blend in this truck type was biocontamination, which in part can be treated with biocidal additives. However, there is no conclusive evidence to support biocontamination as the cause of the filter plugging and operational problems; additional study should be considered. Another significant contributing factor to this problem is probably the way the USPS fuels its trucks. The trucks are filled every night or every other night; often, only 510 gallons of fuel are used from the fuel tank before it is refilled. In this scenario, the fuel in the onboard fuel tank is left unused for a long period and is most likely a contributing factor to the fuel tank sludge buildup.

\section{FORD CARGO VAN RESULTS}

In examining the cylinder heads, combustion chambers, and fuel systems, no significant differences were noted in the teardown of the Fords. The cylinder head cavities of all four engines were clean with only a normal oily residue found in each. The pistons in all of the engines were in good condition with some carbon buildup in the bowl area and above the ring lands (Figure 13). The intake and exhaust valves were clean with light carbon deposits on the sealing surfaces and normal buildup on the valve heads.

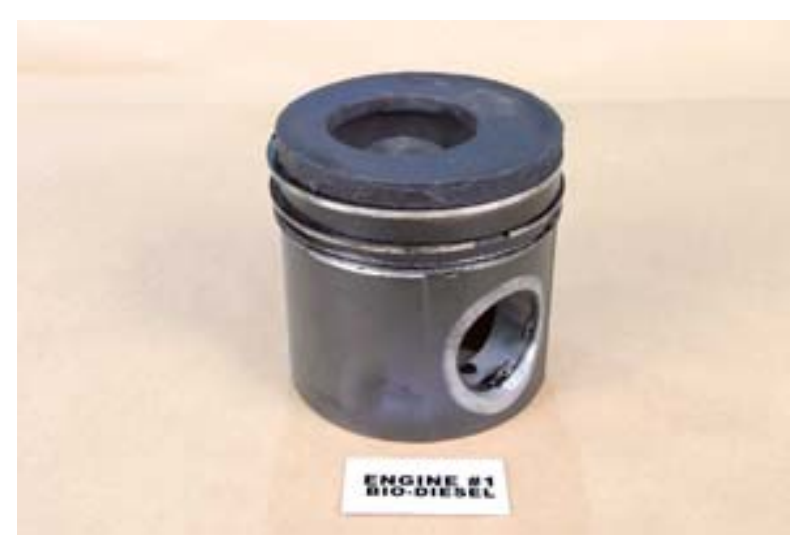

Figure 13. Ford No. 1 B20 Piston Carbon Deposits

The fuel injection pumps and nozzle assemblies were removed and bench tested. All four pumps tested well within specified limits for pressure and flow and were suitable for reuse (with new gaskets and seals). All nozzle assemblies also tested well within acceptable limits. Table 6 details the checks performed on the fuel system. The results shown for the Ford No. 1 B20 engine were typical of the results for all four engines.

Table 6. Ford No. 1 B20 Fuel System Inspection Checklist

\begin{tabular}{|l|l|}
\hline \multicolumn{1}{|c|}{ Part(s) } & \multicolumn{1}{c|}{ General Condition } \\
\hline Injection pump & $\begin{array}{l}\text { Pressures well within } \\
\text { specified limits. Overall } \\
\text { condition good, suitable for } \\
\text { cleaning and reconditioning. }\end{array}$ \\
\hline $\begin{array}{l}\text { Fuel lines, high pressure } \\
\text { (cylinders 1-6) }\end{array}$ & Condition OK, no issues. \\
\hline $\begin{array}{l}\text { Fuel inlet tubes } \\
\text { (cylinders 1-6) }\end{array}$ & Condition OK, no issues. \\
\hline $\begin{array}{l}\text { Injector nozzles } \\
\text { (cylinders 1-6) }\end{array}$ & $\begin{array}{l}\text { Condition good, suitable for } \\
\text { cleaning and reconditioning. }\end{array}$ \\
\hline $\begin{array}{l}\text { Filters, primary and } \\
\text { secondary }\end{array}$ & No issues noted. \\
\hline Fuel supply pump & $\begin{array}{l}\text { Condition good, suitable for } \\
\text { cleaning and reconditioning. }\end{array}$ \\
\hline
\end{tabular}


No issues were found with the lubrication systems and oil pumps of the four Ford engines, but one of the petroleum diesel engines (No. 3 diesel) experienced a lubrication failure resulting in excessive wear of cylinder block and crankcase components. The three other engines had normal wear of the crankshafts, main, and connecting rod bearings with light overlay fatigue and occasional "orange peel."

\section{FORD NO. 3 DIESEL BEARING FAILURE}

Bearings on the No. 3 diesel engine exhibited heavy to severe wear. Main and connecting rod bearings show wear into the copper linings with severe wear at the fourth main journal position, resulting in complete bearing failure (Figure 14).

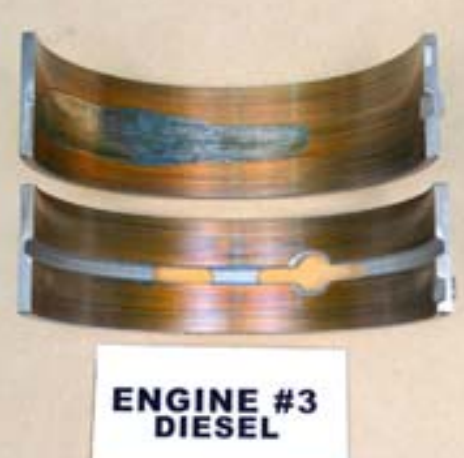

Figure 14. Ford No. 3 Diesel Main Bearing Failure
The lower bearing insert is worn through the copper lining, scoring the crankshaft at the fourth journal position. Severe wear and damage exhibited in the No. 3 diesel engine indicates a lack of lubrication. Maintenance records show that this Ford van had problems that may have indicated or contributed to the lubrication problem; however, there is no conclusive evidence as to the cause of the lack of lubrication.

\section{FORD MAINTENANCE COMPARISON}

Figure 15 shows cumulative engine- and fuel-related maintenance costs for the two study groups of Ford vans. B20 use ended in November 2003. Generally, the B20 Ford vans at the Miami VMF had slightly higher (14\% higher) maintenance costs for the engine- and fuel-related systems than the diesel-only Ford vans at the Tampa VMF. Both of the Ford van study groups had a significant number of maintenance actions for the accelerator pedal and throttle problems that caused significant cost. The Miami B20 vans had more costs associated with this problem, and this accounted for most of the cost difference between the two study groups. This problem does not appear to be related to the use of B20. With the additional accelerator costs removed from the Miami B20 vans, the engine and fuel system maintenance costs are nearly identical to those of the Tampa diesel vans.

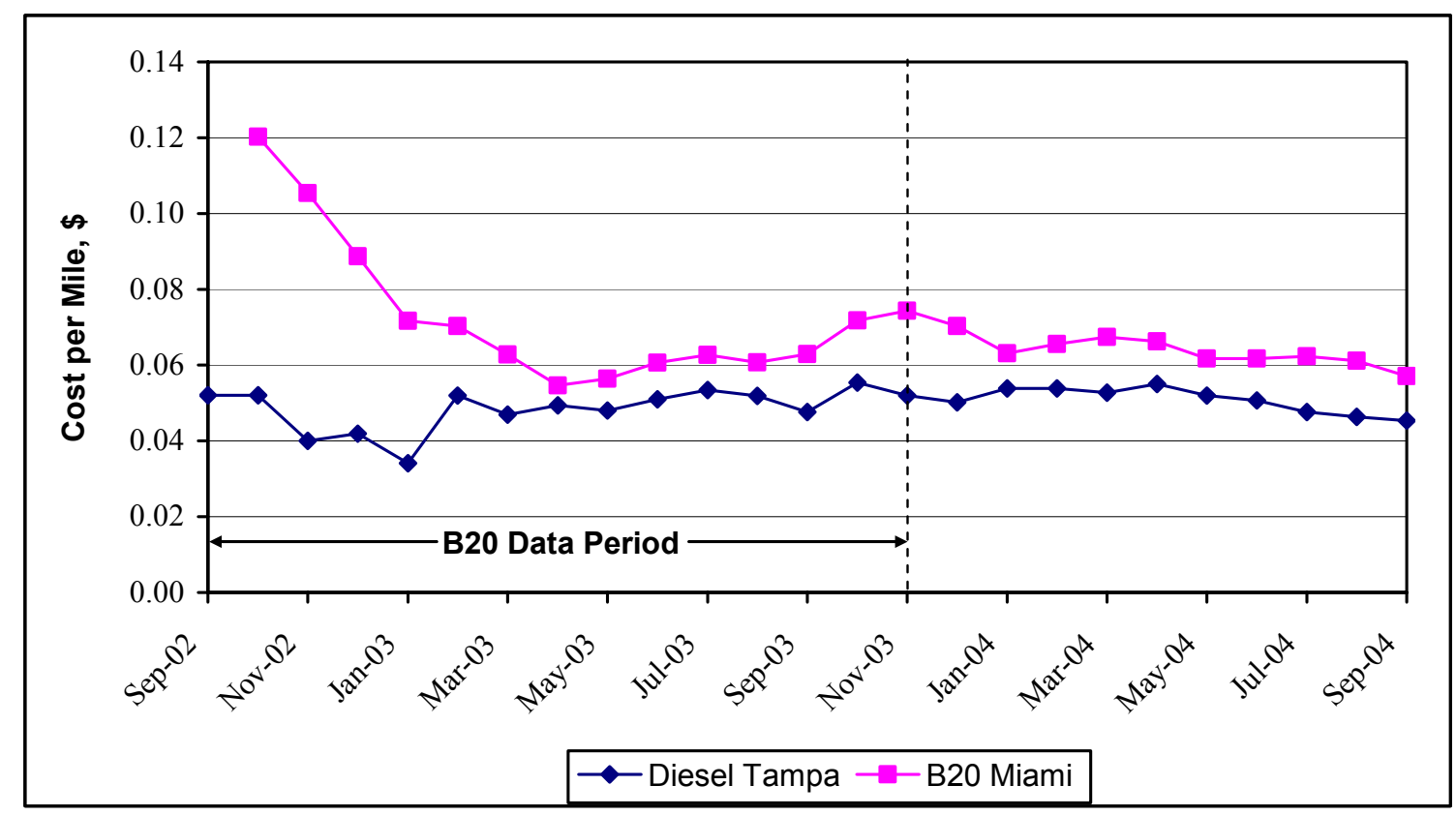

Figure 15. Cumulative Running Average Engine- and Fuel-Related Maintenance Costs per Mile for the Ford Vans. Higher costs to maintain the B20 vehicles are probably not attributable to the fuel, as discussed in the text. 


\section{FUEL SYSTEMS COMPARISON}

The Ford 7.8L engine uses a Bosch P3000 series in-line fuel injection pump. This style of fuel system contains a supply pump to deliver fuel from the tank through a filter to the injection pump. The injection pump feeds highpressure fuel (up to 1,150 bar) via high-pressure lines to the fuel nozzles for injection into the cylinders [17]. A return line brings overflow from the injection pump and fuel from the nozzles back to the fuel tank.

The Mack E7-300 engine uses the same style of Bosch fuel system but has a larger P7100 series in-line fuel injection pump to supply the larger displacement (12L) engine. As suggested earlier, the greater fuel circulation volume was suspected to contribute to the fuel filter plugging evident with the Mack tractors but not the Ford vans. Vehicle installation of the fuel system (filter sizing, plumbing) may also be a contributing factor, but fuel system differences alone do not seem to account for all the differences in results between the Ford and Mack vehicles operating on B20 (e.g., valve deck sludge accumulation, injector replacement, and higher operational costs for filter replacement in the Mack tractors). Duty cycle and engine operation (loading) may also be responsible for susceptibility to B20 use issues.

\section{CONCLUSIONS AND RECOMMENDATIONS}

All engines exhibited normal wear for their mileage, independent of fuel.

Analysis of vehicle operation and engine teardown showed several differences between B20 and petroleum diesel use in the Mack tractors:

- The cylinder heads of the B20 engines contained a heavy amount of sludge around the rocker assemblies that was not found in the diesel engines. Out-of-specification fuel is the suspected cause.

- Both B20 engines required injector nozzle replacement over the evaluation and teardown period, which may be attributable to B20 use and out-of-specification fuel.

- Nevertheless, the B20 tractors had essentially the same maintenance costs as the petroleum diesel tractors with the exception of a single event near the end of the study.

These differences were not observed with the Ford cargo vans. The Ford vans did not have the filter plugging, injector replacement, or sludge accumulation issues noted with the Mack tractors. Differences in fuel and engine system maintenance costs were not attributed to biodiesel-related issues.

Further research and analysis is necessary to determine the susceptibility of different engine and vehicle types to B20-related operating issues. In future evaluations of
B20 operation, controlled data on fuel supply (sampling and analysis) and operational characteristics (duty cycle, loading, etc.) are critical to proving out-of-specification fuel and biocontamination hypotheses, especially when multiple vehicle types are involved. Control and collection of critical data are better with evaluations done in real time (i.e., with continuous monitoring of data collection) than with evaluations that rely on historical data (i.e., analysis conducted after the operational period).

\section{ACKNOWLEDGMENTS}

The authors thank the Engineering, Research and Development Department of the USPS for their support. Special thanks are extended to Powel Bernhardt and Robert Montebello from Philadelphia Vehicles Category Management Center, Les Machek from Miami VMF, Ray Hushon from Fort Lauderdale VMF, Charles Venator from Tampa VMF, and Jim Howell from Roush Industries.

The FreedomCAR and Vehicle Technologies Program, Fuels Technologies Subprogram of the U.S. Department of Energy sponsored the National Renewable Energy Laboratory's participation in this project. The authors thank Ralph Cherillo of Shell Global Solutions and Ted Selby of Savant for assistance in interpretation of the oil and sludge analysis data.

Work was performed in part under the auspices of the U.S. Department of Energy by University of California, Lawrence Livermore National Laboratory under contract W-7405-Eng-48.

\section{REFERENCES}

1. United States Environmental Protection Agency. "A Comprehensive Analysis of Biodiesel Impacts on Exhaust Emissions." Draft Technical Report, EPA420-P-02-001, 2002.

2. Sheehan J., Camobreco V., Duffield J., Graboski M., Shapouri H. "An Overview of Biodiesel and Petroleum Diesel Life Cycles." National Renewable Energy Laboratory, NREL/TP-580-24772, May 1998.

3. Graboski M., McCormick R. "Combustion of Fat and Vegetable Oil Derived Fuels in Diesel Engines." Prog. Energy Combust. Sci.; Vol. 24, 1998; p. 125164

4. Malcosky N.D., Wald T. "Ohio DOT Dump Truck/Snow Plow Comparative Evaluations with a Biodiesel Blend." SAE Technical Paper No. 971688, 1997.

5. Bickel K., Strebig K. "Soy-Based Diesel Fuel Study." Final report to Legislative Commission on Minnesota Resources and Minnesota Soygrowers Association, 2000.

6. Kearney T., Benton J. "Final Report: Air Force Biodiesel Demonstration Program at Scott AFB." 2002. 
7. Humberg D.S., Hansen T.J., Schumacher L.G., Mahapatra A.K., Taylor G.L., Adams B.T. "Biodiesel Use and Experience among State DOT Agencies." ASAE Paper No. 046072, 2004.

8. Chase C.L., Peterson C.L., Lowe G.A., Mann P., Smith J.A., Kado N.Y. "A 322,000 Kilometer (200,000 Mile) Over the Road Test with HySEE Biodiesel in a Heavy Duty Truck." SAE Technical Paper No. 2000-01-2647, 2000.

9. Dinh H.T. "The United States Postal Service Alternative Fuels Utilization Program: A 1999 Overview." SAE Technical Paper No. 1999-01-2897, 1999.

10. United States Postal Service 2004 Biodiesel Data Query (Internal Report). U.S. Postal Service Environmental Management Policy Office, Washington, DC, 2004.

11. Dtn Energy's Alternative Fuels Index; Vol. 3, Issue 30, 2005; p. 2

12. National Biodiesel Board. "Tax Incentive." www.nbb.org/news/taxincentive. Accessed Aug 12, 2005.

13. Cheng A.S., Buchholz B.A., Dibble R.W. "Isotopic Tracing of Fuel Carbon in the Emissions of a Compression-Ignition Engine Fueled With Biodiesel Blends." SAE Technical Paper 2003-01-2282, 2003; SAE Trans. - Journal of Fuels and Lubricants; Vol. 112, 2004; p. 2015-2020.

14. Buchholz B.A., Dibble R.W., Rich D., Cheng A.S. "Quantifying the contribution of lubrication oil carbon to particulate emissions from a diesel engine." SAE Technical Paper 2003-01-1987, 2003; SAE Trans. Journal of Fuels and Lubricants; Vol. 112, 2004; p. 1874-1879.

15. Vogel J.S., Southon J.R., Nelson D.E. "Catalyst and Binder Effects in the Use of Filamentous Graphite for AMS." Nucl. Instrum. Methods Phys. Res. Sect. B; Vol. 29, 1987; p. 50-56.

16. Buchholz B.A., Mueller C.J., Upatnieks A., Martin G.C., Pitz W.J., Westbrook C.K. "Using Carbon-14 Isotope Tracing to Investigate Molecular Structure Effects of the Oxygenate Dibutyl Maleate on Soot Emissions from a DI Diesel Engine." SAE Technical Paper 2004-01-1849, 2004; SAE Trans. - Journal of Fuels and Lubricants; Vol. 113, 2005; p. 846-857.

17. Challen B., Baranescu R., ed. Diesel Engine Reference Book. $2^{\text {nd }}$ edition. Woburn: ButterworthHeinemann, 1999.

\section{DEFINITIONS, ACRONYMS, ABBREVIATIONS}

AMS: Accelerator Mass Spectrometry

ASTM: ASTM International

B20: A blend of $20 \%$ biodiesel with diesel fuel

EPAct: Energy Policy Act

ICP: Inductively coupled plasma

NREL: National Renewable Energy Laboratory

P\&DC: Processing and Distribution Center

USPS: United States Postal Service

VMF: Vehicle Maintenance Facility

ZDDP: Zinc dialkyldithiophosphate 